administration; and lectures, informal talks, or classes upon subjects of particular interest in the museum do not seem to be a regular, or even frequent, feature of the work of the officials. Introductory series, so useful where the uninitiated and schools are concerned, are usually absent; and very rarely indeed, if at all, are collections used to illustrate or teach such matters as, say, the impact of geology upon the mining and building industries, upon road and railway construction, or upon water-supply, etc.; or again, the impact of biology upon medical and veterinary research, upon agriculture, horticulture, and matters of human health, and so on. The average archæological collection (and most South African museums are rich in this material) neither tells the 'story' of prehistoric man in South Africa nor illustrates archæological method. A great deal more, also, could be effected with the usually abundant collections of native material-in the more graphic portrayal of tribal customs, mode of life and social organisation, for example. The brilliant exhibit of life-like models of Bushmen (both male and female) in the South African Museum at Cape Town well illustrates the possibilities in this direction. These figureś, set up in astonishingly realistic attitudes, wear Bushman clothing and carry Bushman weapons of the chase or war, and associated with them are Bushman domestic utensils. Cast from life, these 'living' records of a practically extinct people make the Cape Town Museum unique among all others in the Union.

With few exceptions, the congestion of the average South African museum exhibition-case leaves no room for the treatment of subjects in some of the ways suggested; but considerable improvement would be possible (even without building extensions) if a good half of some of the material exhibited were to be transferred behind the scenes-not to be lost or neglected, but to be suitably and systematically stored for the better use of the student and specialist worker. Several museums, in this way, could make room for better exhibition work in the public galleries.

Other matters which strike one as requiring consideration in the museums of the Union are appointments and retiring ages. At the present time some appointments seem to go to individuals who have already retired from some other walk of life. In the case of directorships or curatorships, especially, it is important that appointments should go to those who have had training and wide experience in museum work and methods, and who can put in a sufficient number of years of service before reaching retiring age. As yet, there seems to be no hard and fast rule as to the age at which a museum official should retire. It is clear. however, that this should be fixed in the interests of any progressive policy of work and service. New ministerial blood at prescribed intervals is a necessity to any institution the primary function of which is public service-and service suitable to the times.

There is, no doubt, a big future for South African museums; in a rapidly developing country they are a cultural necessity. South African museums have already carried out much useful work in scientific research, and vast fields for further study and collection lie before them. As has already been suggested, however, there is room for better work in their educational function, the function which, in the long run, will determine not only their use to the community, but, in addition, their status within it.

J. R. Harding

\section{TWENTY-THIRD ANNUAL CONFERENCE OF ASLIB}

$\mathrm{D}$

URING September 17-20, the twenty-third annual conference of Aslib was held at Ashorne Hill, near Leamington Spa. This Conference resumed, for the first time since 1938, Aslib's residential conferences, which, with the fast-expanding number of special librarians and information officers, are essential if the old and experienced members are to mix informally and discuss the difficulties of the younger and comparatively inexperienced information officers. Some idea of the extent to which this is necessary is given by the growth of Aslib's membership : 1,010 on June 30,1948 ; 827 in 1947 ; and 712 in 1946. At the beginning of the War it was less than 300 . Of the total, research associations and learned societies account for 33 per cent, industrial and commercial organisations 20 per cent, individuals 22 per cent, overseas members 17 per cent, and British Government Departments 8 per cent. These figures give some idea of the extent to which the information officer and special librarian have become essential members of any well-conducted, moderm research establishment and progressive industrial concern.

The report by the director (Miss E. M. R. Ditmas) of the work of Aslib, 1947-48, pointed out that 'Aslib' is now a registered name, and since the amalgamation with the British Society for International Biblio. graphy on January 1, 1948, no longer stands for "Association of Special Libraries and Information Bureaux". The amalgamation added a couple of score of members. The increased amount of work means that a series of afternoon meetings will be held between October 1948 and April 1949, besides the annual conference. Instead, therefore, of an annual publication of Conference Proceedings, there will be a new journal, Aslib Proceedings.

In March 1948 Aslib called the meeting which is now working towards an Institute of Recorded Sound; sixty students attended the Aslib Study Group in August 1947, and seventy in April 1948, and a memorandum on "Training of Information Officers" was drawn up by a Sub-Committee of the Education Committee; the Information and Library Section recorded 2,521 inquiries, had 66 requests for registered translators and supplied 2,275 items through the Documentary Reproduction Service. The Aslib library receives regularly more than 100 periodicals; but lack of suitable premises makes 52 Bloomsbury Street badly overcrowded. At the request of the Department of Scientific and Industrial Research, Aslib set up, in June 1947, its Committee on the Mechanized Distribution of Information to discuss the uses of mechanization in library and technical information work, and supplied a statement to the Royal Society's Conference. In December 1947 the Committee on the Format and Efficiency of Periodicals was set up.

Naturally, Aslib has taken much part in the documentation work of the British Standards Institution, the British National Committee on Documentation and many international and foreign organisations. Sir Richard Gregory was made an honorary member during the year.

Usually the annual conference of Aslib is organised almost as a symposium of papers on one or, perhaps, two subjects of universal interest. This year it was a miscellaneous collection dealing rather more with the existing problems in the fields of the information 
officer and special librarian than with the uttering of any startling ideas or announcements.

Saturday morning, September 18, opened with Dr. R. E. Priestley (vice-chancellor and principal of the University of Birmingham) in the chair. Mr. B. Fullman (British Non-Ferrous Research Association, chairman Aslib Education Committee) opened the proceedings on "The Training of the Information Officer", basing his arguments on a statement which had been circulated confidentially to Aslib members. "Information officers," he said, "are fashionable and no home is complete without them, and they are budgeted for as a matter of course." He urged that Aslib should consider issuing a diploma to ensure that organisations would, in the future, obtain properly qualified people. He emphasized how diverse, yet specialized, is the information officer's work compared with that of the librarian as normally considered. He endorsed a flexible arrangement with the Library Association, but emphasized that the scientific world needs information officers and special librarians who have first obtained a science degree.

Mr. J. S. P. Paton (Metropolitan-Vickers) discussed the questionable necessity for the prospective information officer to have to take the whole of the Library Association's course. He pointed out the need for such special requirements as languages, the ability to speak the language of scientific colleagues and for the necessity for good practical experience of research departments.

Mr. F. G. B. Hutchings (Leeds City librarian and chairman of the Education Committee, Library Association) endeavoured to minimize the difference between librarians and special librarians and information officers by emphasizing the amount of inquiry in public libraries and their closer association with local industrial and scientific organisations. He said that the new Library Association syllabus is "getting to be bibliographical rather than literary". Therefore, why a special Aslib diploma and course ?

The lively discussion from the floor emphasized that the industrial and research intelligence officer makes use of information besides collecting and collating, the necessity for the initial scientific training and the fact that ability in this field cannot always be assessed by examination, but is a natural aptitude. It resulted in the whole matter being referred back to the Aslib Council for further consideration after this preliminary airing of many views.

The Saturday afternoon session, under Dr. E. Marsden (New Zealand Scientific Liaison Office, London), was devoted to Prof. J. D. Bernal talking on "The Significance to Special Librarians and Information Officers of the Royal Society's Scientific Information Conference". He opened by stating, "it depends upon Aslib and Aslib members as to whether the resolutions of the Royal Society are implemented". He referred to Dr. D. J. Urquhart's "Survey of Scientific Reading Habits" and gave in some detail the figures and conclusions given in his own paper, "Preliminary Analysis of Pilot Questionnaire on the Use of Scientific Literature" at the Society's Conference. He raised again the necessity for reprints, or 'separates', and the necessity for the relinquishing of copyright by authors of papers, so that they may be freely reproduced from journals. $\mathrm{H}_{\Theta}$ asked, "Is the liaison between user and the information officer sufficient ?" He mentioned the non-co-ordination between the libraries of scientific institutions in the Bloomsbury area, and how co- ordination had been achieved in his own subject of physics.

Mr. J. E. Cummins (Australian Scientific Research Liaison Office) sketched the library position in Australia, stressing the need for the librarian there to cease "to look upon himself as a keeper of books". Dr. S. R. Ranganathan (president of the Indian Library Association) said that "work in the library world is going on in a casual way without any planning", and called for a special study of "librometry'. The need for proper co-ordination of abstract. ing and suggestions that abstracts be available before or as soon as a paper is ready to be read, and not after the now delayed publication, was mentioned in the discussion, in which a large number partook. It emphasized the difficulties and problems of getting the right information to the right person at the right time. The increasing need for this over the years was clearly recognized when Aslib was founded twenty-four years ago to start creating order out of confusion and to be the prime mover ever since.

Sunday morning, under the chairmanship of Mr. J. F. Stanley (British Standards Institution), opened with Mr. Eric Smythe (librarian and research officer of Reynolds News) discussing the organisation and working of a newspaper's press-cutting library and the mechanics of storage. He emphasized the speed and efficiency with which such a library should work, and that facts are wanted sometimes on immediate notice five minutes before going to press.

Sir Cuthbert Whitaker, in his fifty-fourth year of editorship of Whitaker's Almanack, gave a straightforward account of the "History and Compilation of Whitaker's Almanack". He mentioned how his father, the late Joseph Whitaker, while pacing up and down a garden path, in 1868, remembered the "Commonplace Book" he had compiled when conducting the correspondence columns of the Gentleman's Magazine. $\mathrm{He}$ thought its publication in an organised form, together with meteorological data, which Sir George Airey was delighted to supply, thus justifying the term 'almanack', would be welcomed by the public. The first Almanack for 1869 appeared on December 10,1868 , and had 363 pages and an index of 1,100 entries. The 1948 edition has 1,092 pages and 35,000 references. The plan of the Almanack was so carefully designed by Joseph Whitaker that the main part of the work ever since has been "submitting proofs and reducing the exuberance of corrections".

With Dr. J. C. Withers (Shirley Institute) as chairman, Dr. Hugh Clegg (editor of the British Medical Journal) and Mr. R. Brightman (Imperial Chemical Industries, Ltd.) talked on "The Art and Technique of Book Reviewing". They both emphasized the importance of a review of a scientific or technical book giving "a clear account of what the book is about, indicating both the scope of the book, the scale on which the subject is treated, and the particular type of reader for whom it is intended". Dr. Clegg strongly advocated that all authoritative book reviews should be signed by the reviewer.

Sunday evening was devoted to a discussion on "Practical Applications of International Collabora. tion in Documentation", opened by Mr. E. J. Carter (head of the Library Section, Unesco), who said, "It is becoming clearer that documentation and library services are the very roots of international collaboration". It was essential to bring practical people together to collaborate and surmount language difficulties to give complete and efficient transmission of ideas. This means a properly organised and ade- 
quate secretariat. "Delegates to international conferences must have documents beforehand in their own language to be able to discuss them with their own people." This was strongly supported by Dr. Ranganathan, who pointed out that many confer. ences fail because of quite inadequate preliminary documentation. $\mathrm{He}$ also advocated that older delegates to conferences should be accompanied by a younger man, who would thus be properly experienced when it became his turn to lead. He emphasized how adequate documentation overcame language difficulties, while the use of a universal classification system, such as the U.D.C., prevented misunderstanding as to the precise definition of a subject. Dr. P. Bourgeois (director, Swiss National Library) pointed out that this was not generally being done, and instanced some recent international conferences, which had achieved little because of the paucity of their practical application of documentation.

Mr. A. B. Agard Evans (Ministry of Works Library) said that there were far too many international resolutions, and not enough practical activity. This was due, in some instances, to the lack of national collaboration first, and he directed attention to the fact that the building industry was one of the wealthiest in the world, yet it had little international collaboration.

In association with the conference, Aslib arranged an exhibition of representative bibliographies and abstracting journals. Ivor B. N. Evans

\section{INDIAN DAIRY SCIENCE}

$\mathrm{T}$ HE immense importance of a substantial increase in production and consumption of milk and milk products, both to the balance of Indian agriculture and in contributing protein, fat and minerals to the very largely cereal diet of the $320 \pm 20$ million inhabitants of present-day India is being increasingly appreciated in that country. For perhaps two decades, real efforts have been made to improve the dairy industry in India both as regards milk production (in which Mahatma Gandhi took a personal interest) and as regards milk distribution and manufacture. Progress, hindered by religious as well as economic obstacles, has, however, been rather disappointing.

This slow development has also been due, in no small part, to other causes-paucity of knowledge, the serious shortage of trained dairy husbandrymen and of satisfying opportunities for their activity, the acute lack of dairy scientists, technologists and engineers and the absence of more than a smaIl handful of research workers in dairying. Research is clearly needed in two directions : first, the application to the severer climatic and other conditions of India of the knowledge already applied in the more progressive dairying countries in the temperate zones; and secondly, basic study of the nutrition, breeding and physiology of dairy stock in India and of the microbiology, biochemistry and engineering underlying modern dairying operations.

The recent formation of an Indian Dairy Science Association with similar objects to those of the Society of Dairy Technology in Great Britain, namely, the advancement of dairy science, the provision of opportunities for the exchange of knowledge and ideas, and the encouragement of scientific inquiry into problems arising in the industry, is a step in the right direction. The Association is fortunate in having Sir Datar Singh, the energetic chairman of the Indian Council of Agricultural Research, as its first president. The Association has just issued the first number of a new journal, the Indian Journal of Dairy Science, which is to appear quarterly under the editorship of the director of the Indian Dairy Research Institute at Bangalore, Dr. K. C. Sen (Indian Dairy Science Association, Hosur Road, Bangalore, India. 12 rupees per annum).

The present number contains six original articles dealing with aspects of milk production, control of milk keeping quality, milk composition, milk phosphatase, vegetable rennet and indigenous butter. While it would be unfair to apply too critical an eye to some of these early contributions, they are all of value, and one at least, by Krishnamurti and Subrahmanyan, is outstanding. A promising start has been made, and several in Britain who know at first hand of the immense difficulties which have still to be overcome before the mutually dependent partners, dairy science and the dairying industry, can flourish in India, will look forward with great interest to the future progress of this Journal.

\section{H. D. KAY}

\section{FOREST POLICY IN UGANDA}

A STATEMENT on the forest policy for Uganda was recently issued by His Excellency the Governor and published as a Supplement to the Uganda Gazette of June 15, 1948.

This statement is of interest as it is promulgated by the Governor himself. The main points are as follows: 1. (i) To reserve in perpetuity, for the benefit of the present inhabitants of Uganda and of posterity, sufficient land (either already forested or capable of afforestation) to maintain climatic con. ditions suitable for agriculture, to preserve water supplies, to provide forest produce for agricultural, industrial and domestic purposes, and to maintain soil stability in areas where the land is liable to deterioration if put to other uses. (ii) To manage this forest estate to obtain the best returns on its capital value and the expenses of management, in so far as such returns are consistent with the primary aims set out above. (iii) To foster, by education and propaganda, a real understanding among the people of Uganda of the value of forests to them and their descendants. (iv) To encourage and assist the practice of sound forestry by local authorities and private enterprise; and to educate selected Africans in technical forestry.

It is of interest to note that these points in forest policy were first laid down by the Secretary of State for India in London as far back as 1862. They have since been repeated by many governments in many parts of the world, but only rarely have been given practical effect.

The Governor continues: 2. To achieve the first objective of this four-point policy, namely, the creation of an adequate forest estate, the following guiding principles shall be observed : (i) The climatic and physical conditions of the country must be preserved and, if possible, bettered, by first, the reservation of suitable land, and secondly, the maintenance, improvement or re-establishment of vegetation on the most important catchment areas and on other strategic positions. (ii) The supply in perpetuity of the many forms of forest produce required 